\title{
INSURABLE INTEREST UNDER LIFE INSURANCE AND FAMILY TAKAFUL
}

\author{
Yusuf Sani Abubakar ${ }^{1}$ \\ Muhammad Anowar Zahid ${ }^{2}$ \\ Ruzian Markom ${ }^{3}$
}

\begin{abstract}
This is a doctrinal and comparative research between the traditional law and the Shariah with regard to insurable interest. The paper aims to examine Shariah views regarding individuals that have an insurable interest in the eyes of the traditional law; and also to clarify these persons' right to insurable interest in the Islamic version of insurance i.e. takaful based on the rights of these individuals upon each other in Shariah. The paper suggests that insurable interest in family takaful could be justified based on inheritance law (al-mīräth), bequest (al-wașiyyah), and debt.
\end{abstract}

Keywords: insurable interest, life insurance, family takaful, spouse, child

\footnotetext{
PhD Candidate, Faculty of Law, National University of Malaysia, Bangi, Selangor, Yusuf700@gmail.com

2 Senior Lecturer, Faculty of Law, National University of Malaysia, Bangi, Selangor, anowar_zahid@ukm.my

3 Senior Lecturer, Faculty of Law, National University of Malaysia, Bangi, Selangor, ruzian@ukm.my
} 


\section{INTRODUCTION}

The history of insurable interest in life insurance policies dated back to 1774 when the doctrine was established by statute. ${ }^{4}$ The doctrine of insurable interest requires that the person taking out insurance must show that he or she will either benefit from the continuation of the subject matter of the insurance or will suffer difficulty if the insured subject is lost. Although an insurable interest cannot be defined with complete precision or certainty, in general it is such interest, arising from the relations of the party obtaining the insurance, either as a creditor of or surety for the assured, or from the ties of blood or marriage to him that will justify a reasonable expectation of advantage or benefit from the continuance of his life. ${ }^{5}$

The research would look into individuals that have insurable interest under the traditional law and make a comparison with the Shariah. Traditional law in this research refers to English and Malaysian Insurance law. The discussion on insurable interest would be on spouse, child, illegitimate child, homosexual partner, ward, employee, creditor, debtor, divorced couple and brother or sister. The paper would suggest that justification for insurable interest under family takaful should be based on inheritance law (al-mīrāth), ${ }^{6}$ bequest (alwașiyyah), ${ }^{7}$ and debt.

4 S. M. Atmeh, 'Regulation Not Prohibition: The Comparative Case Against the Insurable Interest Doctrine,' Northwestern Journal of International Law \& Business (2011): 97-98.

$5 \quad$ Liss v. Liss, 937 So. 2d 760, 764 (Fla. $4^{\text {th }}$ Dist. Ct. App. 2006).

6 Al-Mìräth is the Islamic Inheritance Law (Fara'id) that has been pre-ordained by Allah (May He be exalted) in a wise and gradual manner to allow for its compatibility with the judiciary and human nature.

7 Al-Wașiyyah or Will in Islamic terminology is "all instruction a person leaves for tasks to be carried out after his death." Some scholars specify that wașiyyah describes the instructions one leaves to donate money after his death and the instructions to his relatives to commit to righteous behavior. These instructions related to money left as gift or grants (waqf) for certain causes as well as personal decisions one takes to arrange for matters after his death such as caring for his children, funeral and burial arrangements, the marriage of his children, etc. 


\section{INSURABLE INTEREST UNDER THE TRADITIONAL LAW}

Under the English Law, it is required that, for a person to get a benefit from the policy, he/she must have an insurable interest ${ }^{8}$ and must be nominated by the policy holder; otherwise he/she may be disqualified from receiving any benefits because he is not considered as a legal beneficiary. ${ }^{9}$ In Malaysia, by virtue of Section 5 (1) of the Civil Law Act, ${ }^{10}$ the beneficiary in a policy must have an existing insurable interest, ${ }^{11}$ and must be nominated by the policyholder. ${ }^{12}$ Once these conditions are fulfilled a nominee is considered as an absolute beneficiary. ${ }^{13}$ However, if these conditions are not met, any person that claims the benefits under the policy as beneficiary may not be able to succeed.

In Malaysia, there are certain persons that are considered to have insurable interest in a person's life such as his/her spouse and children ${ }^{14}$ ("child" includes an illegitimate child, a step-child and a child adopted under any written law of Malaysia or of any place outside Malaysia, or under a custom recognized by a class of persons in or outside Malaysia"), ${ }^{15}$ or ward being under the age of majority at the time of the insurance is effected, and employee. ${ }^{16}$

Under the English Law, besides, a female life partner (who is dependent on her male partner policyholder for support and maintenance) ${ }^{17}$ a homosexual partner; ${ }^{18}$ and an illegitimate child ${ }^{19}$ were included in the persons that have an insurable interest. Moreover, a creditor has an insurable interest in his debtor's

8 Insurable interest exists when an insured person derives a financial or other kind of benefit from the continuous existence of the insured object (or in the context of living persons, their continued survival).

9 Section 18 of the Gaming Act 1845 (UK).

10 See section 5 of the Civil Law Act 1956.

11 See 23 (1) of the Civil Law Act 1956; see also section 152 (1) (2) of the Insurance Act 1996.

12 See 23 (1) of the Civil Law Act 1956; see also section 166 (1) of the Insurance Act 1996.

13 [1965] 2 MLJ 1 See also [1974] 1 MLJ 14.

14 Section 152 (2) (a) of the Insurance Act 1996.

15 Section 2 of the Insurance Act 1996.

16 Section 152 (2) (a) of the Insurance Act 1996.

17 Nik Ramlah Mahmood, Insurance Law in Malaysia (Butterworths, Malaysia, 1992), 33.

18 Nik Ramlah Mahmood, Insurance Law in Malaysia, 33.

19 Section 19 (1) of the Family Law Reform Act 1969 (UK). 
life to the extent of his debt. ${ }^{20} \mathrm{~A}$ debtor has no insurable interest in the life of his creditor. ${ }^{21}$ There is no insurable interest for divorced couple except where as a consequence of divorce, some financial arrangements had been made or ordered by the court e.g. maintenance, then the ex wife would have an insurable interest. Again there is no insurable interest for brother or sister ${ }^{22}$ except where he or she is wholly or partially dependent on the other for support.

\section{DOCTRINE OF INSURABLE INTEREST UNDER FAMILY TAKAFUL}

According to Prof. Masum Billah, insurable interest should be designed in order to ensure that takaful operates with a meaningful spirit. ${ }^{23}$ Moreover, the Shariah Advisory Council of Bank Negara mentioned that the concept of insurable interest does not contradict the Shariah and it may be applied in takaful. ${ }^{24}$ Under family takaful, by virtue of the Islamic Financial Services Act 2013, it has been provided that a takaful participant entering into a contract of family takaful shall have a permissible takaful interest in the person covered at the time such contract is entered into and at the time the takaful benefits are payable. Furthermore, a person shall be deemed to have a permissible takaful interest in the person covered if that other person is his spouse or child; his ward under the age of majority at the time the person entered into the contract of takaful; his employee; or a person whom he is wholly or partly dependent for maintenance or education at the time he entered into the contract of takaful. ${ }^{25}$ Moreover, during the ISRA Shari' ah Scholars Dialogue, it has been suggested that beneficiaries under the policy should be restricted to those with insurable interest only and should only be restricted to the legal heirs. ${ }^{26}$

\footnotetext{
20 Dalby v. India \& London Life Assurance Co [1854] 15 CB 365.

21 Houseman and Davies, Law of Life Assurance, $11^{\text {th }}$ ed. (UK: LexisNexis, 2001), 22.

22 Peter Hamilton, Life Assurance Law and Practice (Sweet and Maxwell, 1995), A 1.30 .

23 Mohd. Ma'sum Billah, 'Insurable Interest: Can the Modern Law Be Adopted in Takaful Operations?' Arab Law Quarterly, 15/2 (2002): 207-209.

24 Bank Negara Malaysia, 'The SAC, in its 52 ${ }^{\text {nd }}$ meeting dated 2 August 2005 and $76^{\text {th }}$ meeting on 9 June 2008,' retrieved from www.bnm.gov.my/guidelines

25 Schedule 8, Section 140, Paragraph 3. (1), (2) \& (6) of the Islamic Financial Services Act 2013.

26 International Shari'ah Research Academy for Islamic Finance (ISRA), 'International Shari'ah Scholars Dialogue,' (2008), retrieved from http://www. isra.my/site-map/quick-link/previous-event/230-international-shari-ah-scholarsdialogue-issd-2008.html
} 
Basically, insurable interest in traditional law concept cannot be wholly applied to the Shariah. The reason is that under family takaful, unlike life insurance, the participant in the takaful certificate is not insured, but he or she is just participating in a contract of mutual cooperation. Therefore, under family takaful, justification for insurable interest should be based on inheritance law (al-mīräth), bequest (al-wașiyyah), and debt as the takaful benefits are considered as part of the participant's estate after his death. Therefore, for a person to get any benefit from the takaful benefits there must be a justification recognized by the Shariah that would allow someone to benefit from a deceased's property after his death, and hence insurable interest under family takaful should be looked from this angle.

\section{COMPARISON}

This part of the research would draw a comparison between life insurance and family takaful with regard to insurable interest. This would be explained further below:

\section{Spouse}

According to Section 152 (2) (a) of the Insurance Act 1996, spouses have an insurable interest over each other. ${ }^{27} \mathrm{~A}$ husband, thus, has an insurable interest over his wife and vice versa. Before determining insurable interest between husbands and wives under the Shariah, we need to refer to their rights over each other first. Firstly, under the Shariah, it is compulsory for the husband to give the dowry to the wife. Allah (May He be exalted) says:

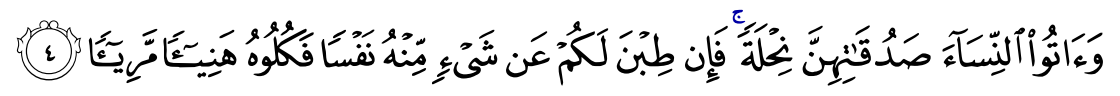

"And give the women (whom you marry) their Mahr (Obligatory bridal money given by the husband to his wife at the time of marriage) with a good heart, but if they, of their own good pleasure remit a part of it to you, take it, and enjoy it without fear of any harm (as Allah has made it lawful)."

(Surah al-Nisā', 4: 4)

Moreover, under the Shariah, a wife is financially independent from her husband. Islam has accorded wife independent personality and assured her full capability to be financially independent from her husband. Thus, a wife has

$27 \quad$ Section 152 (2) (a) of the Insurance Act 1996. 
the right to earn money, own property, enter into legal contracts and manage all her assets in any way she wants. She has the right to own a business and acquire assets. Allah (May He be exalted) says:

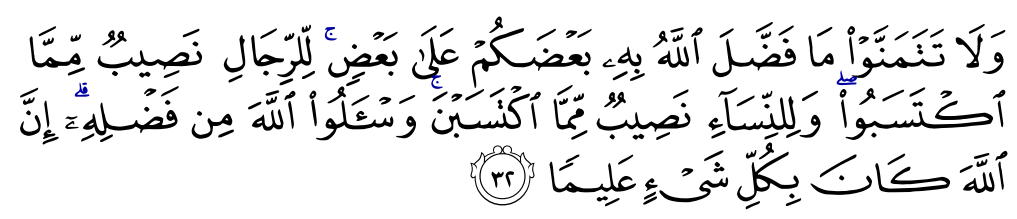

"And in no wise covet those things in which Allah hath bestowed his gifts more freely on some of you on others: to men is allotted what they earn and to woman what they earn: but ask Allah of his bounty for Allah hath full knowledge of all things."

(Surah al-Nisā', 4: 32)

This was manifested in the house of the Prophet (peace and blessings of Allah upon Him) Khadijah, his wife (May Allah be pleased with her) was a very successful trader. Before her marriage with the Prophet (peace and blessings of Allah upon Him), he managed her trade, and after the marriage the Prophet (peace and blessings of Allah upon Him) never asked Khadijah (May Allah be pleased with her) to spend any money even for Islam, but voluntarily spent a lot of money whenever she felt that it is for the benefits of Islam.

Moreover, the husband is financially completely responsible for his wife, poor or rich. Her living costs are estimated in proportion to her husband's financial ability. Allah (May He be exalted) says:

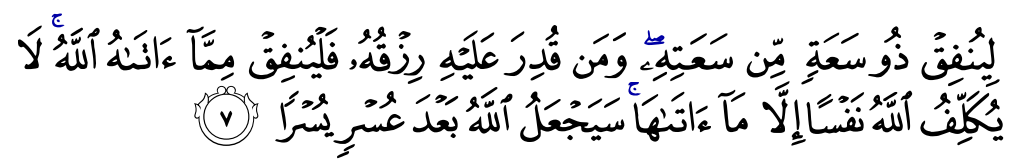

"Let the man of means spend according to his means: and the man whose resources are restricted, let him spend according to what Allah has given him. Allah puts no burden on any person beyond what He has given him. After a difficulty, Allah will soon grant relief."

(Surah al-Ṭalāq, 65: 7)

And both husband and wife have been given the right to inherit one another after death. A husband inherits from the property left behind by his wife and vice versa. Allah (May He be exalted) says: 


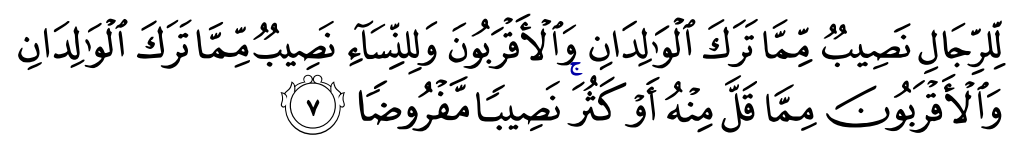

"From what is left by parents and those nearest related there is a share for men and a share for women, whether the property be small or large,-a determinate share."

(Surah al-Nisā', 4: 7)

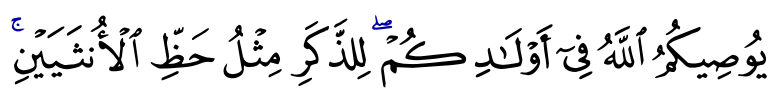

"Allah (thus) directs you as regards your Children's (Inheritance): to the male, a portion equal to that of two female."

Allah (May He be exalted) also says:

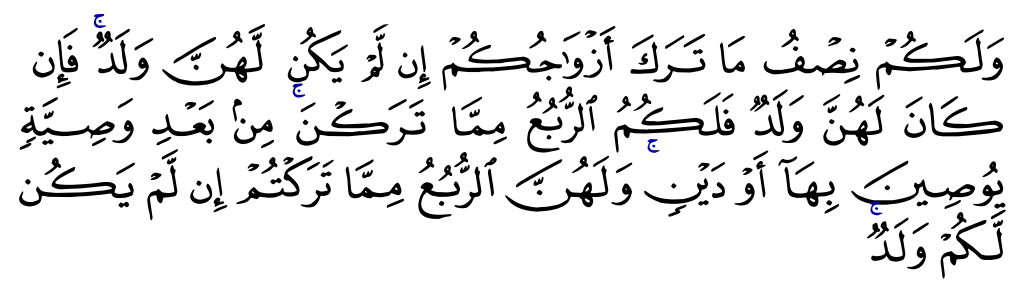

"In what your wives leave, your share is a half, if they leave no child; but if they leave a child, ye get a fourth; after payment of legacies and debts. In what ye leave, their share is a fourth, if ye leave no child."

(Surah al-Nisā', 4: 12)

Thus, it is submitted that under takaful a wife should have an insurable interest in the policy benefits in the following situations:

(a) If the husband does not give her dowry until he dies, and there is no any other property to pay her from except the policy benefits. In this case, her dowry must be paid from the benefits even if nothing will remain for the legal heirs, because this is a debt on the husband and must be settled;

(b) If the wife spends some part of her wealth in running the marital house, may be due to inability of her husband to provide for the family. If she claims back what she spent, it must be returned to her even if nothing will remain for the legal heirs as it is considered a debt, as spending for the family is the husband's responsibility; and 
(c) If the husband passes away, the wife must get her own share of inheritance out of the policy benefits based on the portion mentioned in the Holy Quran. As for the husband, it is submitted that he should have a justification for insurable interest in the takaful benefits of his wife after her death depending on his share of inheritance as specified by the Holy Quran.

\section{Child}

According to Section 152 (2) (a) of the Insurance Act 1996, a child has an insurable interest over his parent. ${ }^{28}$ But, in England a person had no insurable interest in the life of his parent ${ }^{29}$ because a child has no right against his parents to support him. Unless the parents are legally obliged to support the child, there would be no insurable interest. An example of this would be where a maintenance order has been made against a parent compelling the parent to provide for the child. On the death of the parent the child would suffer financially by the losing the one that will support him. To ensure that his child will continuously to receive a financial support, his parent can take life policy on his life by either nominating him/her as beneficiary or assigning the proceeds on adulthood. ${ }^{30}$

Under takaful, before establishing insurable interest between children and parents, it is essential to look into the responsibilities of parents and children to each other under the Shariah. With regard to the responsibility of parents towards children, it is the duty of the father to take care of his children. And this covers providing food, drink, clothing, shelter etc. Allah (May He be exalted) says:

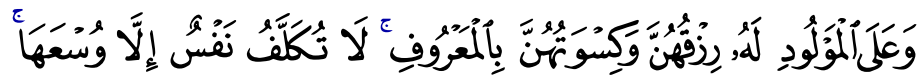

"..but the father of the child shall bear the cost of the mother's food and clothing on a reasonable basis. No person shall have a burden laid on him greater than he can bear."

(Surah al-Baqarah, 2: 233)

\footnotetext{
$28 \quad$ Section 152 (2) (a) of the Insurance Act 1996.

29 Howard v. Refuge Friendly Society [1886] 54 LT 644; In Scotland, a parent has the right to be supported by the child and vice versa and therefore each has an interest in the life of the other.

30 S. S. Dass, Law of Life Insurance in Malaysia (Malaysia: Alpha Sigma Sdn. Bhd., 2000), 7.
} 
As for the responsibilities of children towards parent, Allah (May He be exalted) has ordained kindness to one's parents. Allah (May He be exalted) says:

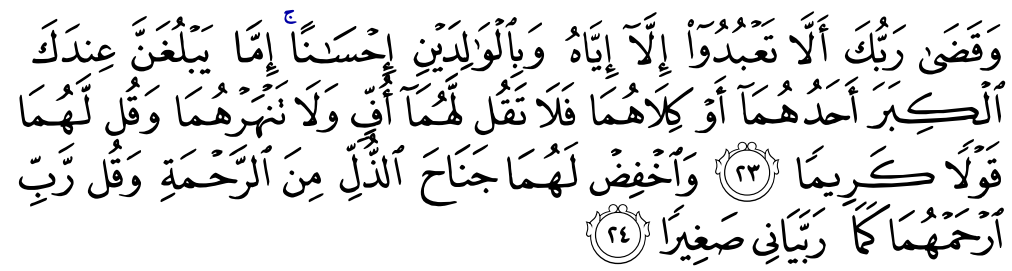

"Your Lord has decreed that you worship none but Him. And that you be dutiful to your parents. If one of them or both of them attain old age in your life, say not to them a word of disrespect, nor shout at them but address them in terms of honor. And lower unto them the wing of submission and humility through mercy, and say, 'My Lord! Bestow on them Your Mercy as they did bring me up when I was young."

(Surah al-Isrā', 17: 23-24)

Again, the Shariah has given parents and children the right to inherit each other from the wealth left behind after death. Allah (May He be exalted) says:

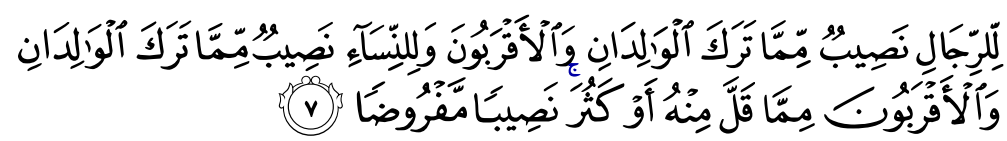

"From what is left by parents and those nearest related there is a share for men and a share for women, whether the property be small or large,-a determinate share."

(Surah al-Nisā', 4: 7)

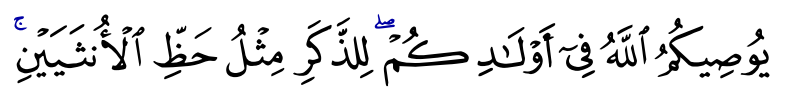

"Allah (thus) directs you as regards your children's (inheritance): to the male, a portion equal to that of two females..."

(Surah al-Nisā’, 4: 11) 


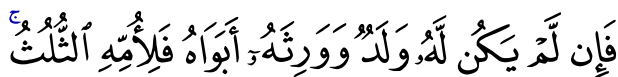

"..If there is no children and the parents are the (only) heirs, the mother has a third.."

(Surah al-Nisā', 4: 11)

From the aforementioned authorities, it is clear that in Islam both parents and children have the duty to take the responsibility of one another. The parents are obliged to take the responsibility of their children until the age of puberty and for daughters until marriage. As for the children, they shall be responsible to take care of their parents from the age of puberty. ${ }^{31}$ Moreover, Islam has given parents the authority to deal with the wealth of their children within certain conditions. Furthermore, both children and parents are given the right to inherit one another from the wealth left after death.

Therefore, it is submitted that a child in the following situations should have the right to benefit from the takaful benefits:

(a) Where the father is obliged to feed the son, but he did not and the mother uses her money to do that. If after the death of the father, the amount spent by the mother is still not settled by the father, and the only wealth left by the father is the policy benefits, the mother must be paid from it even if nothing will remain for the legal heirs;

(b) Where the father or mother policy holder/participant passed away, the son shall have his own share of the inheritance from the policy benefits based on the portion he or she deserves under the Islamic Law of Inheritance. However, the son should not claim for the return of his personal wealth used by his father from the father's policy benefits after his death based on the hadith mentioned above both the son and his wealth belonged to the father.

As for the parents, it is submitted that they should have an insurable interest in the policy benefits in the following situations:

(a) If the son borrowed some money from his parents, they can claim the return of their money from the takaful benefits even if that is the only wealth left by the son, as the money borrowed by the son is a debt that must be settled;

$31 \quad$ Anon, 'Children's right in Islam,' http://www.islamicislamic.com/parents.htm\#1. PARENTS_RIGHTS_, accessed on 14 June 2015. 
(b) Where the son, policy holder/participant passed away, the parents must get their own share of inheritance from the policy benefits based on their portion specified by the Shariah.

Thus, the Shariah is different from the traditional law pertaining to the rights of children over parent and vice versa. Under the Shariah both parents and children have responsibilities over one another. And as for insurable interest, parents would have an insurable interest over son if the son owes some money to the parents, and the parents also have an insurable interest to inherit from the policy benefits of their son policyholder/participant based on their portion provided by the Shariah.

\section{Illegitimate Child}

By virtue of Section 2 of the Insurance Act 1996 and Section 19(1) of the Family Law Reform Act 1969 (UK), an illegitimate child has an insurable interest on his parent. According to Section 2 of the Insurance Act 1996, ("child" includes an illegitimate child, a step-child and a child adopted under any written law of Malaysia or of any place outside Malaysia, or under a custom recognized by a class of persons in or outside Malaysia"). ${ }^{32}$

With regard to takaful, Islam does not recognize the status of an illegitimate child and that of legitimated child. Furthermore, in Islam the status of an adopted child is not equal to that of a natural child. Therefore, where a Muslim mentions that the benefits under a family takaful certificate are for his children, this only refers to natural children. ${ }^{33}$ According to the Shariah, an illegitimate child is not allowed to inherit his biological father, and the biological father also cannot inherit the illegitimate child as well. In a hadith, Amr bin Shuaib reported from his father who reported from his grandfather that the Messenger of Allah (May He be exalted) said: whoso fornicates with a free woman or a slave girl, the issue is an illegitimate child. He shall neither inherit nor be inherited. ${ }^{34}$

According to Hanafi, Maliki, Shafi'i and Hanbali Schools of Law, the restriction imposed on an illegitimate child in inheritance is limited to the property of the biological father and the paternal relatives. However, the

32 Section 2 of the Insurance Act 1996; Section 19 (1) of the Family Law Reform Act 1969 (UK).

33 Nik Ramlah Mahmood, Insurance Law in Malaysia, 214.

34 M. Fazlul Karim, Mishkatul Masabih (Lahore: The Law Book House, 1939), 333. 
illegitimate child is not barred from inheriting his mother's or a maternal relative's property. ${ }^{35}$ From this, it could be said that under the Shariah, an illegitimate child has a justification for insurable interest in the policy benefits of his mother but not his father. This is because the Shariah does not allow an illegitimate child to inherit the property of the biological father and paternal relatives, but is allowed to inherit from his mother's or maternal relative's property. However, it is suggested that an illegitimate child may have a justification for insurable interest from his biological father based al-wașiyyah because he is a non-heir and is entitled for al-wasiyyah.

\section{Homosexual Partner}

Based on the traditional law, a homosexual partner has an insurable interest. ${ }^{36}$ Couples of same sex, thus, have an insurable interest over one another, and might be nominated under a trust policy, and the nominee under the policy receives the benefits as beneficiary.

As for the position of homosexual partners under the Shariah, Islam strongly forbids homosexuality. ${ }^{37}$ There are various verses in the Holy Quran which are cited as referring to gay and lesbian behaviours. The verses were related to people of Lut, and the sin of homosexuality led to their destruction. Allah (May He be exalted) says:

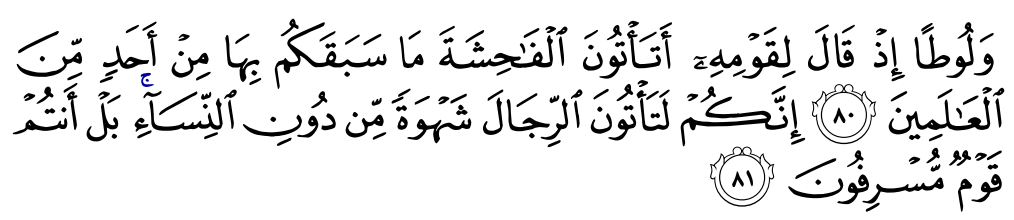

"We also sent Lut: He said to his people: "Do ye commit lewdness such as no people in creation (ever) committed before you? For ye practice your lusts on men in preference to women: ye are indeed a people transgressing beyond bounds."

(Surah al-A'rāf, 7: 80-81)

Allah (May He be exalted) also says:

\footnotetext{
35 Abu Laith Samarqandi, Khazanah al-Fiqh, Baghdad, 1/412; Section 47 of the Qanun al-Mawarith, no. 77 of 1943 of Egypt, http://kenanaonline.com/users/ foxrever/posts/257323, accessed on 14 June 2015.

36 Nik Ramlah Mahmood, Insurance Law in Malaysia, 33.

37 Tariq Ramadan, 'Islam and Homosexuality,' http://www.tariqramadan.com/spip. php?article10683\&lang=fr, accessed on 02 June 2013.
} 


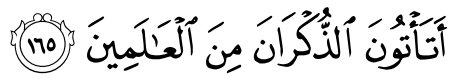

"What! Of all creatures do ye come unto the males, and leave the wives your Lord created for you? Nay, but ye are forward folk."

(Surah al-Shu'arā', 26: 165)

Therefore, it submitted that under the Shariah, the homosexual partner should have no insurable interest over the other partner. This is because their cohabitation is illegal, as under the Shariah for couples to inherit one another, there must be a legal marriage that fulfills all the conditions prescribed by the Shariah. Hence, the traditional law totally contradicts the Shariah by allowing a homosexual partner to have an insurable interest over the other homosexual partner.

\section{Ward}

According to Section 152 (2) (a) of the Insurance Act 1996, a guardian has an insurable interest on his ward who is under the age of majority at the time of the insurance contract is completed ${ }^{38}$ because a guardian is under a legal obligation to maintain his ward. Under the Shariah, ward could be referred to a situation where a child has been put under the guardian of someone. Or the person himself adopts the child in order to take his responsibilities. In as much as it is compulsory on the guardian to discharge his responsibilities in taking care of the child as promised by himself. But the ward or adopted child has no right to inherit the guardian. The ward or adopted child is still not considered as the guardian's child. The following verse illustrates this fact:

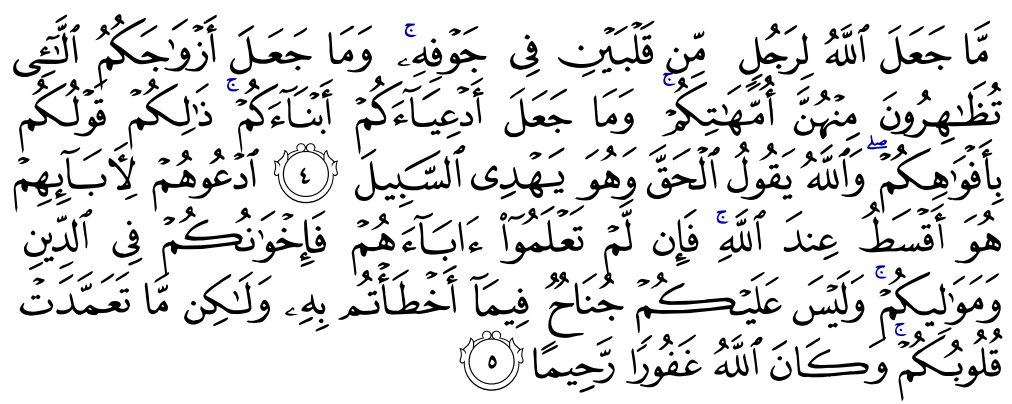

"Allah has not made for any man two hearts in his (one) body:

38 Section 152 (2) (a) of the Insurance Act 1996; Anctil v. Manufacturers' Life Insurance Co [1899] AC 604. 
nor has He made your wives whom ye divorce by Zihar your mothers: nor has He made your adopted sons your sons. Such is (only) your (manner of) speech by your mouths. But Allah tells (you) the Truth, and He shows the (right) Way. Call them by (the names of) their fathers: that is juster in the sight of Allah. But if ye know not their father's (names, call them) your Brothers in faith, or your maulas. But there is no blame on you if ye make a mistake therein: (what counts is) the intention of your hearts: and Allah is Oft-Returning, Most Merciful."

(Surah al-Aḥzāb, 33: 4-5)

The above verse indicates that adopted sons are not real sons, and this ruling can also be extended to ward because he or she is also not a real son. Therefore, since under the Shariah, the ward has no right to inherit from the guardian's property including the policy benefits, it is suggested that a ward may have a justification for insurable based on al-wașiyyah.

\section{Employee}

By virtue of Section 152 (2) (a) of the Insurance Act 1996, an employee may have an insurable interest ${ }^{39}$ if the employee is under a contract for a fixed term up to the amount of his salary to be paid during that period. ${ }^{40}$ The employeremployee relationship is considered a hiring relationship, and there are Shariah principles that govern it. According to the Shariah, it is the right of the employee to have his wages specified in advance by the employer and to get it completely and on time. Abū Sa ${ }^{\top} \overline{1} d$ al-Khudrī narrated that the Prophet (peace and blessings of Allah upon Him) said:

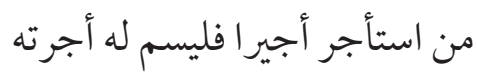

"Whoever employs someone to work for him; he must specify for him his wages in advance." ${ }^{41}$

Therefore, if the employee is under a contract for a fixed term, if the employer policyholder/participant purchases a policy, after he passes away, if there is no other money from the employer's estate except the policy benefits,

\footnotetext{
39 Section 152 (2) (a) of the Insurance Act 1996

40 Hebdon v. West [1863] 3 B \& S 579

41 Reported by 'Abd al-Razzāq, Musannaf, Kitab al-Buyu, vol. 8 (Karachi: al-Majlis al-'Ilmi, 1972), 235.
} 
the employee should be paid from the policy benefits until the period he worked for the employer before he passes away and not more. This is because the employee is only entitled to get his salary up to the last period he worked for the employer before he passes away.

Hence, it is submitted that the employee should be paid from the policy benefits even if nothing will remain for the legal heirs, as it is a debt on the employer. Moreover, the employee may also be justified to benefit from the takaful benefits based on al-wașiyyah.

\section{Creditor}

Based on the traditional law, a creditor has an insurable interest in his debtor's life to the extent of his debt. ${ }^{42}$ The Shariah has given a creditor a big right in claiming back his money from the debtor. The Prophet (peace and blessings of Allah upon Him) said in a hadith narrated by Abū Hurayrah (may Allah be pleased with him):

$$
\text { أيسا امرئ أفلس ، ووجد رجل سلعته عنده بعينها فهو أولى بها من غيره }
$$

"If anyone goes bankrupt and a man finds his own property intact with him, he is more entitled to it than anyone else." 43

In another hadith narrated by Abū Mūsā (may Allah be pleased with him) from the Prophet (peace and blessings of Allah upon Him) who said:

$$
\begin{aligned}
& \text { إن أعظم الذنوب عند الله تعالى أن يلقاه بها عبد- بعد الكبائر التي نهى الله } \\
& \text { عنها- أن يموت رجل الدون وعليه دين لا يدع له قضاء }
\end{aligned}
$$

"Verily the greatest of sins to Allah (May He be exalted) with which a man shall meet him after the great sins which Allah (May He be exalted) prohibited is his debt outstanding at death but leaving nothing for its settlement." 44

42 Dalby v. India \& London Life Assurance Co [1854] 15 CB 365.

43 Reported by Abū Hurayrah, Abū 'Abd Allāh Muhammad bin 'Abd Allāh al-Hakim al-Naysaburi, al-Mustadrak ala al-Șah̄ịayn, vol. 1 (Beirūt: Dār al-Ma'rifah, 1988), 452.

44 Narrated by Abū Mūsā al-Ash'arī, Muhammad Shams al-Dīn al-Ḥaq al-'Az̄īm $\bar{A}$ badī, 'Awn al-Ma'bud, Sharh Sunan $A b \bar{\imath}$ Dāwūd, vol. 1 (Beirūt: Dār al-Fikr, 1995), 74. 
Again, debt is something that must be settled as even a martyr may not be forgiven if he is martyred with a debt. The Prophet (peace and blessings of Allah upon Him) said in a hadith narrated by 'Abd Allāh bin Amr bin al-As (may Allah be pleased with him):

$$
\begin{aligned}
& \text { يغفر للشهيد كل ذنب إلا الدين } \\
& \text { "Every sin of a martyr shall be forgiven except debt." } 45
\end{aligned}
$$

Therefore, if the debtor policyholder/participant passes away and has no wealth to settle his debt from, the debt must be settled from the policy benefits even if nothing will remain for the legal heirs. Thus, it is submitted that the creditor should have an insurable interest as the Shariah requires that the rights of creditors must be returned. Again, a creditor may have a justification for insurable interest based on al-wasiiyyah.

\section{Debtor}

Under the traditional law, a debtor has no insurable interest in the life of his creditor. ${ }^{46}$ Basically, under the Shariah, debtor does not have insurable interest. This is because; a debtor is the one, who owes some amount to the creditor, and it is illogical to claim that the debtor has an insurable interest as he is the one that supposes to settle the amount he owes. Moreover, claiming an insurable interest by a creditor will amount to consuming other people's property unjustly. ${ }^{47}$ However, a debtor may have a justification for insurable interest based on al-wașiyyah.

\section{Divorced Couple}

Based on the traditional law, there is no insurable interest for divorced couple except where as a consequence of divorce, some financial arrangements had been made or ordered by the court. For example, where maintenance is yet to

45 Narrated by 'Abd Allāh bin Amr bin al-'As, Muslim bin Hajjaj al-Qushayri al-Naysaburi, Sahīḥ Muslim, Kitāb al-Imārah (Cairo: Dār Iḥyā al-Kutub al'Arabiyyah), 171.

46 Houseman and Davies, Law of Life Assurance, 22.

47 "O ye who believe! Eat not up your property among yourselves in vanities: But let there be amongst you Traffic and trade by mutual good-will: Nor kill (or destroy) yourselves: for verily Allah hath been to you Most Merciful!' (Surah al-Nisā', 4: 29). 
be paid, then the wife would have an insurable interest. ${ }^{48}$ Under the Shariah, Islam has given a divorced wife certain rights. For example, if the husband delayed payment of the dowry agreed upon in the contract, he will continue to be liable for the payment. Moreover, the husband must pay for her maintenance of food, drink and living quarters for a certain period of time, known as iddah. The husband must also pay for his children's financial maintenance, and for the wet nurses to breast feed them. If the mother breast feeds them herself, the father must compensate her for that, as Allah (May He be exalted) said:

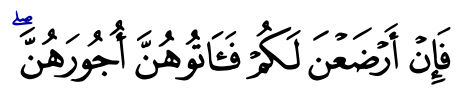

"And if they suckle your (offspring) give them their recompense."

(Surah al-Ṭalāq, 65: 6)

Therefore, under the Shariah, it is suggested that a divorced wife should have an insurable interest in the following situations:

(a) Where the husband policyholder/participant has not given her dowry until he passes away, in this case the dowry must be paid from the policy benefits even if nothing will remain for the legal heirs, as the dowry is a debt on the husband;

(b) Where there is an arrangement made by the court with regard to the maintenance of the ex-wife, she will then have an insurable interest to get the maintenance cost from the policy benefits, even if that will consume the whole benefits, because it is a debt on the husband policyholder/ participant; and

(c) And where out of kindness the husband makes a will (al-wașiyyah) for the divorced wife. The husband may also have a justification for insurable interest from the takaful benefits of his ex-wife based on al-wașiyyah.

\section{Brother or Sister}

Under the traditional law, there is no insurable interest for brother or sister. ${ }^{49}$ However, if one of them is wholly or partially dependent on the other for support, there is an insurable interest. ${ }^{50}$ As for family takaful, the Shariah has ordained kindness to relatives. A brother or sister to someone is amongst his closest relatives. The Messenger of Allah (peace and blessings of Allah upon Him) said:

\footnotetext{
48 Peter Hamilton, Life Assurance Law and Practice, A 1.30.

49 Peter Hamilton, Life Assurance Law and Practice, A 1.30.

50 Section 152(2) of the Insurance Act 1996.
} 


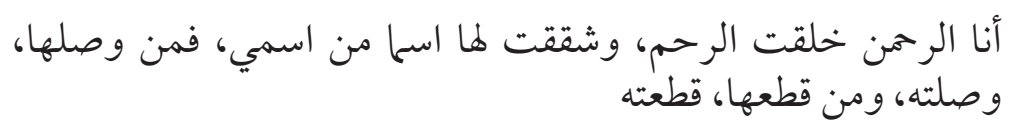

"Allah says: 'I am al-Rahmān (the Most Merciful) and this rahm (tie of kinship) has a name that is derived from my name. Whoever uphold it, I will take care of him, and whoever severs it, I will cut him off." 51

In another hadith, the Prophet (peace and blessings of Allah upon Him) said:

$$
\text { من أحب أن يبسط له في رزقه، وينسأ له في أثره، فليصل رحمه . }
$$

"Whoever would like his lifespan to be extended and his provision to be increased, let him uphold the ties of kinship." 52

Therefore, the Shariah commands supporting relatives especially when they are poor, by providing them food, cloth, shelter and etc. However, the fact that they are being supported by the brother does not entitled them to have insurable interest in his life i.e. to inherit from his wealth after his death if he has children and parent. But a brother or sister may inherit from his brother's or sister's property after his death in certain circumstances. The below verse illustrates this situation:

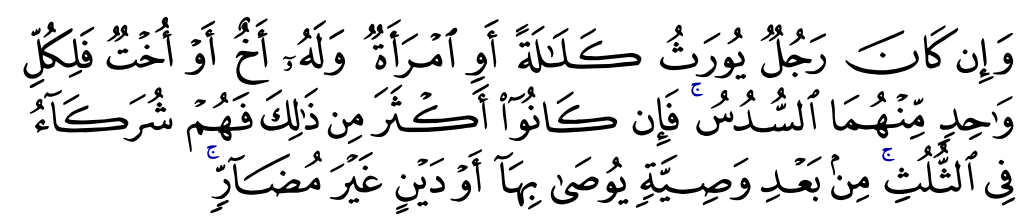

"If the man or woman whose inheritance is in question, has left neither ascendants nor descendants, but has left a brother or a sister, each one of the two gets a sixth; but if more than two, they share in a third; after payment of legacies and debts; "

(Surah al-Nisā̄', 4: 12)

Therefore, under the Shariah, a brother or sister may have insurable interest in the policy benefits of his brother or sister, if he or she has no children and parents. In this situation a brother or sister may inherit from the policy benefits.

\footnotetext{
51 Zayn al-Dīn Muhammad, al-Ittihafāt al-Sunniyyah bi al-Ahāàìth al-Qudsiyyah, vol. 1 (Beirūt: Dār Ibn Kathīr, n.d.), 70.

52 Abū 'Abd Allāh 'Abd al-Raḥmān bin Nașir, Bahjat Qulūb al-Abrār wa Qurrat 'uyun al-Akhyār fì Sharh Jawāmi' al-Akhbar, vol. 1 (Saudi 'Arabia: Ministry of Islamic Affairs), 172.
} 
A brother or sister may also have a justification for insurable interest based on al-wașiyyah.

\section{CONCLUSION}

Under the English law, it is required that, for a person to get a benefit from the policy, he/she must have an insurable interest and must be nominated by the policy holder; otherwise he/she may be disqualified from receiving any benefits because he is not considered as a legal beneficiary. The doctrine of insurable interest requires that the person taking out insurance must show that he or she will either benefit from the continuation of the subject matter of the insurance or will suffer difficulty if the insured subject is lost.

Basically, insurable interest in traditional law concept cannot be wholly applied to the Shariah. The reason is that under family takaful, unlike life insurance, the participant in the takaful certificate is not insured, but he or she is just participating in a contract of mutual cooperation. Therefore, under family takaful, justification for insurable interest should be based on inheritance law (almìräth), bequest (al-wașiyyah), and debt as the takaful benefits are considered as part of the participant's estate after his death. Therefore, for a person to get any benefit from the takaful benefits there must be a justification recognized by the Shariah that would allow someone to benefit from a deceased's property after his death, and hence insurable interest under family takaful should be looked from this angle.

\section{REFERENCES}

'Abd Allāh bin Amr bin al-'As, Muslim bin Hajjaj al-Qushayri al-Naysaburi, Sahīh Muslim, Kitāb al-Imārah (Cairo: Dār Iḥyā al-Kutub al'Arabiyyah).

'Abd al-Razzāq, Musannaf, Kitāb al-Buyu, vol. 8 (Karachi: al-Majlis al-'Ilmi, 1972).

Abū 'Abd Allāh 'Abd al-Raḥmān bin Nașir, Bahjat Qulūb al-Abrār wa Qurrat 'uyun al-Akhyār fi Sharh Jawāmi' al-Akhbar, vol. 1 (Saudi 'Arabia: Ministry of Islamic Affairs).

Abū Hurayrah, Abū 'Abd Allāh Muḥammad bin 'Abd Allāh al-Hakim alNaysaburi, al-Mustadrak ala al-Ṣaḥihayn, vol. 1 (Beirūt: Dār alMa'rifah, 1988).

Abu Laith Samarqandi, Khazanah al-Fiqh, Baghdad, vol. 1. (n.p.: n.p., n.d.).

Abū Mūsā al-Ash ‘arī, Muḥammad Shams al-Dīn al-Ḥa al-'Aẓīm Ābadī, ‘Awn al-Ma‘bud, Sharh Sunan Abī Dāwūd, vol. 1 (Beirūt: Dār al-Fikr, 1995). 
Anon, 'Children's right in Islam,' http://www.islamicislamic.com/parents. htm\#1._PARENTS_RIGHTS, accessed on 14 June 2015.

Bank Negara Malaysia, '52nd meeting of the Shariah Advisory Council,' retrieved from www.bnm.gov.my/guidelines, accessed on 14 June 2015.

Houseman and Davis, Law of Life Assurance (UK: LexisNexis, 2001).

Imam Malik bin Anas, al-Muwatta, Kitab al-Buyu, Book 31, Hadith 1375 (Beirūt: Dār al-Ihyya al-Turāth al-'Arabī, t.t.).

Imam Malik bin Anas, al-Muwatta of Imam Malik Ibn Anas (Oxon: Routledge, the Islamic Classical Library, 2010), 276.

International Shari'ah Research Academy for Islamic Finance (ISRA), 'International Shari'ah Scholars Dialogue,' retrieved from http://www. isra.my/site-map/quick-link/previous-event/230-international-shari-ahscholars-dialogue-issd-2008.html, accessed on 14 June 2015.

M. Fazlul Karim, Mishkatul Masabih (Lahore: The Law Book House, 1939).

Mohd Masum Billah, 'Insurable Interest: Can the Modern Law Be Adopted in Takaful Operations?’ Arab Law Quarterly, 15/2 (2002).

Muhammad bin Ismā'īl, al-Bukhārī, al-Adab al-Mufrad (Egypt: al-Matba'ah al-Taziyah, $1349 \mathrm{H})$.

Nik Ramlah Mahmood, The Insurance Law in Malaysia (Kuala Lumpur: Butterworths, 1992).

Peter Hamilton, Life Assurance Law and Practice (Sweet and Maxwell, 1995).

S. M. Atmeh, 'Regulation Not Prohibition: The Comparative Case Against the Insurable Interest Doctrine,' Northwestern Journal of International Law \& Business, 32/1 (2011).

S. S. Dass, Law of Life Insurance in Malaysia (Malaysia: Alpha Sigma Sdn. Bhd., 2000).

Tariq Ramadan, 'Islam and Homosexuality,' http://www.tariqramadan.com/ spip.php?article10683\&lang= fr, accessed 15 June 2015.

Zayn al-Dīn Muḥammad, al-Ittihafāt al-Sunniyyah bi al-Ahāàith al-Qudsiyyah, vol. 1 (Beirūt: Dār Ibn Kathīr, n.d.). 


\section{Statutes}

Civil Law Act 1956.

Family Law Reform Act 1969 (UK).

Gaming Act 1845 (UK).

Insurance Act 1996.

Islamic Financial Services Act 2013.

Qanun al-Mawarith, No. 77 of 1943 of Egypt.

\section{Cases}

Anctil v. Manufacturers' Life Insurance Co [1899] AC 604.

Dalby v. India \& London Life Assurance Co [1854] 15 CB 365.

Hebdon v. West [1863] 3 B \& S 579.

Howard v. Refuge Friendly Society [1886] 54 LT 644.

Liss v. Liss, 937 So. 2d 760, 764 (Fla. $4^{\text {th }}$ Dist. Ct. App. 2006). 
Jurnal Syariah, Jil. 23, Bil. 2 (2015) 343-364 